\title{
Survey Minat Masyarakat Untuk Olahraga Rekreasi Bersepeda Pada Masa Pandemi Covid 19 di Kabupaten Demak
}

\author{
Taufik Hidayat ${ }^{1}$, Maftukin Hudah ${ }^{2}$, Utvi Hinda Zhannisa ${ }^{3}$ \\ Universitas PGRI Semarang. Jl. Sidodadi Timur No 24 - Dr. cipto, Semarang, \\ E-mail : taufikh2602@gmail.com
}

\begin{abstract}
Central Java is one of the areas in Indonesia that is affected by the covid 19 virus. Therefore, the Central Java government also carries out instructions given by the central government to prevent the spread of the covid 19 virus. The government imposes social distancing and also Work From Home. However, what happens is that people in the Central Java region are looking for activities outside the home by cycling. This is also experienced by people in the Demak district. The problem taken in this study is how the public's interest in recreational sports cycling during the Covid 19 pandemic in Demak. This study used a quantitative descriptive design with a survey method conducted online by distributing questionnaires via Google Form. The population in this study were bicycle users in the Demak area with a sample size of 100 people. The data analysis technique used percentage descriptive analysis. The results showed that the most dominant indicator was the indicator of attention with a score of $78 \%$ in the high category. The overall results in this study are $75 \%$ in the high category. This shows that people's interest in recreational sports during the Covid 19 pandemic is in the high category. The conclusion in this study is that people's interest in recreational sports cycling during the Covid 19 pandemic is in the high category with a percentage of $75 \%$ with an average score of 282 . People with very high criteria are 24 people, high criteria are 73 people, and criteria are sufficient. as many as 3 people. The public believes that cycling is a suitable sport to do during a pandemic, during a pandemic, health is the thing that we must protect the most because the body is susceptible to viruses. By cycling we can still maintain the health protocols that have been implemented during this pandemic.
\end{abstract}

Keywords: public interest, recreational sports cycling, covid 19

\begin{abstract}
Abstrak
Jawa Tengah merupakan salah satu daerah yang ada di Indonesia yang terdampak oleh virus covid 19. Oleh sebab itu pemerintah Jawa Tengah juga melakukan instruksi yang diberikan oleh pemerintah pusat untuk mencegah persebaran dari virus covid 19. Pemerintah memberlakukan social distancing dan juga Work From Home. Namun yang terjadi masyarakat diwilayah Jawa Tengah justru mencari aktifitas diluar rumah dengan bersepeda. Hal tersebut juga dialami oleh masyarakat dilingkungan kabupaten Demak. Permasalahan yang diambil dalam penelitian ini adalah bagaimana minat masyarakat untuk olahraga rekreasi bersepeda pada masa pandemi covid 19 di Demak. Penelitian ini menggunakan desain deskriptif kuantitatif dengan metode survey yang dilakukan secara online dengan menyebar angket melalui google form.Populasi dalam penelitian ini adalah pengguna sepeda diwilayah Demak dengan jumlah sampel 100 orang. Teknik analisis data menggunakan analisis deskriptif persentase. Hasil penelitian menunjukkan bahwa indikator yang paling dominan adalah indikator perhatian dengan perolehan skor persentase $78 \%$ masuk pada kategori tinggi. Untuk hasil keseluruhan dalam penelitian ini adalah $75 \%$ masuk pada kategori tinggi. Hal tersebut menunjukkan bahwa minat masyarakat untuk olahraga rekreasi pada masa pandemi covid 19 masuk dalam kategori tinggi. Kesimpulan dalam penelitian ini adalah minat masyarakat untuk olahraga rekreasi bersepeda pada masa pandemi covid 19 masuk dalam kategori tinggi dengan pensentase $75 \%$ dengan perolehan skor rata-rata 282. Masyarakat dengan kriteria sangat tinggi sebanyak 24 orang, kriteria tinggi sebanyak 73 orang, dan kriteria cukup sebanyak 3 orang. Masyarakat berpendapat bahwa bersepeda merupakan olahraga yang cocok yang dilakukan pada masa pandemi, pada masa pandemi kesehatan merupakan hal yang harus paling kita jaga karena tubuh rentan terkena virus. Dengan bersepeda kita masih bisa menjaga protokol kesehatan yang telah diterapkan dimasa pandemi ini.
\end{abstract}

Kata kunci: minat masyarakat, olahraga rekreasi bersepeda, covid 19 
Survey minat masyarakat untuk olahraga rekreasi Bersepeda pada masa pandemi covid 19 di demak Taufik hidayat, maftukin hudah, utvi hinda zhannisa,

\section{PENDAHULUAN}

Olahraga adalah suatu bentuk aktivitas fisik yang terencana dan terstruktur yang melibatkan gerakan tubuh berulang-ulang dan ditujukan untuk meningkatkan kebugaran jasmani. Olahraga merupakan sebagian kebutuhan pokok dalam kehidupan sehari-hari karena dapat meningkatkan kebugaran yang diperlukan dalam melakukan tugasnya (Suratmin, 2018:23).

Menurut Kemal dan Supandi dalam Utomo (2015:2), mengungkapkan beberapa definisi olahraga ditinjau dari kata asalnya yaitu (1) disport/disportare, yaitu bergerak dari suatu tempat ke tempat lain (menghindarkan diri). Olahraga adalah suatu permulaan dari dan menimbulkan keinginan orang untuk menghindarkan diri atau melibatkan diri dalam kesenangan (rekreasi), (2) field sport, mula-mula dikenal di inggris abad ke-18. Kegiatannya dilakukan oleh para bangsawan/aristocrat, terdiri dari dua kegiatan pokok yaitu menembak dan berburu pada waktu senggang. (3) desporter, berarti membuang lelah (bahasa perancis). (4) sport, sebagai pemuasan atau hobi (ensiklopedia jerman). (5) olahraga, latihan gerak badan untuk menguatkan badan, seperti berenang, main bola, dan sebagainya. Olahraga adalah usaha mengolah, melatih raga/tubuh manusia untuk menjadi sehat dan kuat.

Olahraga merupakan kegiatan yang terbuka bagi semua orang sesuai dengan kemampuan, kesenangan, dan kesempatan. Tanpa membedakan hak, status sosial, dan derajat dimasyarakat, olahraga dilakukan oleh berbagai unsur lapisan masyarakat (Rosdiani, 2013:62).

Dalam Undang-Undang Nomor 3 Tahun 2005 tentang Sistem Keolahragaan Nasional Pasal 19 ayat (1) Olahraga rekreasi dilakukan sebagai bagian proses pemulihan kembali kesehatan dan kebugaran. (2) Olahraga rekreasi dapat dilaksanakan oleh setiap orang, satuan pendidikan, lembaga perkumpulan, atau organisasi olahraga. (3) Olahraga rekreasi sebagaimana yang dimaksud pada ayat (1) bertujuan: a. memperoleh kesehatan, kebugaran jasmani dan kegembiraan;b. membangun hubungan sosial dan/atau; c. melestarikan dan meningkatkan kekayaan budaya daerah dan nasional.

Olahraga rekreasi adalah suatu kegiatan olahraga yang dilakukan pada waktu senggang sehingga pelaku memperoleh kepuasan secara emosional seperti kesenangan, kegembiraan, kebahagiaan, serta memperoleh kepuasan secara fisik-fisiologis seperti terpeliharanya kesehatan dan kebugaran tubuh, sehingga tercapainya kesehatan secara menyeluruh. Rekreasi merupakan kegiatan positif yang dilakukan pada waktu senggang dengan sungguh-sungguh dan bertujuan untuk mencapai kepuasan (Husdarta dalam Setiyowati 2015:30).

Banyak sekali jenis-jenis olahraga rekreasi yang dapat dilakukan salah satunya yaitu bersepeda. Sepeda adalah sebuah alat transportasi yang dikayuh menggunakan kedua kaki yang meluncur dijalan raya. Sepeda merupakan sarana transpotasi yang hemat.Selain itu sepeda juga sebagai alat bersenangsenang, melakukan petualangan, dan menjaga kesehatan (Munasifah, 2019:1).

Indonesia merupakan salah satu negara yang terdampak oleh virus covid 19. Virus ini sangat mematikan karena proses penyebarannya yang sangat cepat dan menyerang sistem pernafasan sehingga seseorang yang terinfeksi oleh virus ini akan kesulitan untuk bernafas. Hal ini yang dapat menyebabkan 
Survey minat masyarakat untuk olahraga rekreasi Bersepeda pada masa pandemi covid 19 di demak Taufik hidayat, maftukin hudah, utvi hinda zhannisa,

kematian. Mengingat dari dampak yang mematikan dari virus covid 19 membuat pemerintah harus berfikir keras untuk mengantisipasi persebaran virus tersebut, termasuk juga pemerintah diwilayah Jawa Tengah.

Jawa Tengah merupakan salah satu daerah yang ada di Indonesia yang terdampak oleh virus covid 19. Oleh sebab itu pemerintah Jawa Tengah juga melakukan instruksi yang diberikan oleh pemerintah pusat untuk mencegah persebaran dari virus covid 19. Pemerintah memberlakukan social distancing dan juga Work From Home. Berdasarkan keputusan tersebut membuat masyarakat mengurangi aktifitas diluar rumah. Jika melakukan aktifitas diluar rumah masyarakat juga harus menerapkan protokol kesehatan dengan menjaga jarak, mencuci tangan menggunakan sabun, dan memakai masker.

Namun yang terjadi masyarakat diwilayah Jawa Tengah justru mencari aktifitas diluar rumah dengan bersepeda. Hal tersebut juga dialami oleh masyarakat dilingkungan kabupaten Demak.

Berdasarkan wawancara yang dilakukan oleh peneliti pada tanggal 23 Juli dengan ketua Komunitas Gowes Trengguli yaitu : Pada masa pandemi tubuh seseorang mudah terserang oleh virus corona dengan melakukan aktifitas bersepeda dapat meningkatkan sistem kekebalan tubuh agar terhindar dari berbagai serangan penyakit atau virus. Dengan bersepeda kita masih bisa menerapkan protokol kesehatan seperti mencuci tangan, memakai masker, dan menjaga jarak. Selain meningkatkan sistem kekebalan tubuh masih banyak manfaat yang didapatkan dengan aktifitas bersepeda antara lain : menambah wawasan, menyatukan perbedaan, dan dapat menambah teman.

Wawancara kedua dengan ketua Komunitas Demak Sepeda Lipat (Dek Seli) pada tanggal 23 Juli yaitu: Bersepeda merupakan sarana untuk menyalurkan hobi, dengan kegiatan bersepeda kita masih dapat menjaga jarak, saat bersepeda masih tetap bisa menerapkan protokol kesehatan yang telah ditetapkan. Banyak manfaat yang diperoleh dari aktifitas bersepeda, seseorang menjadi senang karena bisa sekalian wisata, sebagai sarana mencari teman, dan bersepeda sebagai sarana untuk terapi agar tubuh tetap sehat.

Hasil wawancara yang terakhir dengan ketua Komunitas Gowes Kuncir (GOKU) pada tanggal 25 Juli yaitu: Pada masa pandemi bersepeda sangat penting untuk menjaga imun agar tubuh kebal dari serangan virus-virus. Bersepeda merupakan aktifitas yang simpel dan dilakukan oleh semua orang baik kalangan anak-anak, orang dewasa, maupun lanjut usia. Manfaat lain yang diperoleh dari kegiatan bersepeda adalah dapat menghilangkan rasa jenuh, dapat bersilaturahmi dengan pesepeda lain, badan menjadi bugar dan dengan bersepeda kita mendapatkan kesenangan tersendiri.

Berdasarkan latar belakang diatas peneliti ingin mengukur minat masyarakat untuk bersepeda pada masa pandemi covid 19 di Demak dengan judul penelitian "Survey minat masyarakat untuk olahraga rekreasi bersepeda pada masa pandemi covid 19 di Demak". 
Survey minat masyarakat untuk olahraga rekreasi Bersepeda pada masa pandemi covid 19 di demak Taufik hidayat, maftukin hudah, utvi hinda zhannisa,

\section{METODE}

Penelitian ini menggunakan desain penelitian deskriptif dengan pendekatan kuantitatif. Dalam penelitian ini menggunakan Simple Random Sampling. Jumlah sampel dalam penelitian ini adalah 100 responden. Dalam penelitian ini teknik pengumpulan data dengan menggunakan observasi, kuesioner, wawancara, dokumentasi. Adapun teknik analisis data yang digunakan dalam penelitian ini adalah teknik analisis deskriptif persentase. Adapun rumus yang digunakan adalah sebagai berikut:

$\mathrm{DP}=\frac{n}{N} \times 100 \%$

Keterangan :

$\mathrm{n}$ : Jumlah skor yang diperoleh data

$\mathrm{N}$ : Jumlah skor ideal (maksimal)

DP : Nilai dalam persen (\%)

\section{HASIL DAN PEMBAHASAN}

Penelitian ini dilakukan diwilayah Kabupaten Demak. Demak merupakan salah satu kabupaten di Provinsi Jawa Tengah. Dalam pengambilan data penelitian dilakukan selama 1 minggu yaitu pada hari Kamis 1 Oktober 2020 sampai Rabu 7 Oktober 2020. Dalam penelitian ini menggunakan teknik analisis data deskriptif persentase. Teknik ini digunakan untuk mengetahui seberapa besar minat masyarakat untuk olahraga rekreasi bersepeda pada masa pandemi covid 19 di Demak. Pengambilan data dilakukan dengan menyebar angket melalui google form yang diberikan kepada 100 responden dengan menjawab item pernyataan yang terdiri 75 item pernyataan.

Berdasarkan hasil penelitian yang diperoleh secara keseluruhan skor rata-rata yang didapatkan oleh responden adalah 282 dengan persentase $75 \%$ maka dikategorikan kriteria tinggi. Untuk perolehan hasil minat masyarakat untuk olahraga rekreasi bersepeda adalah sebagai berikut:

Tabel 1. Distribusi Frekuensi Minat masyarakat

\begin{tabular}{rccc}
\hline No & Persentase & Kriteria & Frekuensi \\
\hline $\mathbf{1}$ & $81 \%-100 \%$ & Sangat Tinggi & 24 \\
\hline $\mathbf{2}$ & $61 \%-80 \%$ & Tinggi & 73 \\
\hline $\mathbf{3}$ & $41 \%-60 \%$ & Cukup & 3 \\
\hline $\mathbf{4}$ & $21 \%-40 \%$ & Kurang & 0 \\
\hline $\mathbf{5}$ & $0 \%-20 \%$ & Sangat Kurang & 0 \\
\hline & Jumlah & 100 \\
\hline
\end{tabular}

Berdasarkan tabel distribusi frekuensi diatas dapat diketahui bahwa terdapat 24 orang masuk dalam kategori sangat tinggi, 73 orang masuk dalam kategori tinggi, dan 3 orang masuk dalam kategori cukup. Dari hasil tabel diatas menandakan bahwa minat masyarakat untuk bersepeda pada masa 
Survey minat masyarakat untuk olahraga rekreasi Bersepeda pada masa pandemi covid 19 di demak Taufik hidayat, maftukin hudah, utvi hinda zhannisa,

pandemi termasuk dalam kategori tinggi. Untuk mengetahui kriteria keseluruhan dari minat masyarakat untuk olahraga rekreasi bersepeda pada masa pandemi di Demak maka dilakukan analisis deskriptif persentase berdasarkan indikator dalam instrumen penelitian. Adapun deskriptif persentase berdasarkan persentase adalah sebagai berikut:

1. Indikator Perhatian

Dalam indikator perhatian terdapat lima belas item pernyataan. Pernyataan yang telah dijawab oleh responden memperoleh skor rata-rata 58 dengan persentase $78 \%$ masuk kedalam kategori tinggi. Untuk mengetahui hasil persentase dapat dilihat pada tabel sebagai berikut:

Tabel 2. Distribusi Minat Masyarakat Indikator Perhatian

\begin{tabular}{cccc}
\hline No & Persentase & Kriteria & Frekuensi \\
\hline $\mathbf{1}$ & $81 \%-100 \%$ & Sangat Tinggi & 40 \\
\hline $\mathbf{2}$ & $61 \%-80 \%$ & Tinggi & 57 \\
\hline $\mathbf{3}$ & $41 \%-60 \%$ & Cukup & 3 \\
\hline $\mathbf{4}$ & $21 \%-40 \%$ & Rendah & 0 \\
\hline $\mathbf{5}$ & $0 \%-20 \%$ & Sangat Rendah & 0 \\
\hline \multicolumn{3}{c}{ Jumlah } & 100 \\
\hline
\end{tabular}

Berdasarkan dari gambar diatas dapat diketahui bahwa terdapat 40 orang mempunyai perhatian yang sangat tinggi, 57 orang mempunyai perhatian yang tinggi, dan 3 orang mempunyai perhatian yang cukup.

Dari hasil tersebut dapat disimpulkan bahwa masyarakat mempunyai perhatian yang tinggi terhadap minat bersepeda pada masa pandemi covid 19.

\section{Indikator Kesenangan}

Dalam indikator kesenangan terdapat lima belas item pernyataan. Pernyataan yang telah dijawab oleh responden memperoleh skor rata-rata 56 dengan persentase $75 \%$ masuk kedalam kategori tinggi. Untuk mengetahui hasil persentase dapat dilihat pada tabel sebagai berikut:

Tabel 3. Distribusi Minat Masyarakat Indikator Kesenangan

\begin{tabular}{cccc}
\hline No & Persentase & Kriteria & Frekuensi \\
\hline $\mathbf{1}$ & $81 \%-100 \%$ & Sangat Tinggi & 26 \\
\hline
\end{tabular}




\begin{tabular}{cccc}
\hline $\mathbf{2}$ & $61 \%-80 \%$ & Tinggi & 68 \\
\hline $\mathbf{3}$ & $41 \%-60 \%$ & Cukup & 6 \\
\hline $\mathbf{4}$ & $21 \%-40 \%$ & Rendah & 0 \\
\hline $\mathbf{5}$ & $0 \%-20 \%$ & Sangat Rendah & 0 \\
\hline \multicolumn{5}{c}{ Jumlah } & 100 \\
\hline
\end{tabular}

Berdasarkan dari gambar diatas dapat diketahui bahwa terdapat 26 orang mempunyai kesenangan yang sangat tinggi, 68 orang mempunyai kesenangan yang tinggi, dan 6 orang mempunyai kesenangan yang cukup. Dari hasil tersebut dapat disimpulkan bahwa masyarakat mempunyai kesenangan yang tinggi terhadap minat bersepeda pada masa pandemi covid 19.

3. Indikator Kemauan

Dalam indikator kemauan terdapat lima belas item pernyataan. Pernyataan yang telah dijawab oleh responden memperoleh skor rata-rata 56 dengan persentase $75 \%$ masuk kedalam kategori tinggi. Untuk mengetahui hasil persentase dapat dilihat pada tabel sebagai berikut:

Tabel 4. Distribusi Minat Masyarakat Indikator Kemauan

\begin{tabular}{cccc}
\hline No & Persentase & Kriteria & Frekuensi \\
\hline $\mathbf{1}$ & $81 \%-100 \%$ & Sangat Tinggi & 25 \\
\hline $\mathbf{2}$ & $61 \%-80 \%$ & Tinggi & 70 \\
\hline $\mathbf{3}$ & $41 \%-60 \%$ & Cukup & 4 \\
\hline $\mathbf{4}$ & $21 \%-40 \%$ & Rendah & 1 \\
\hline $\mathbf{5}$ & $0 \%-20 \%$ & Sangat Rendah & 0 \\
\hline \multicolumn{3}{c}{ Jumlah } & 100 \\
\hline
\end{tabular}

Berdasarkan dari gambar diatas dapat diketahui bahwa terdapat 25 orang mempunyai kemauan yang sangat tinggi, 70 orang mempunyai kemauan yang tinggi, 4 orang mempunyai kemauan yang cukup, dan 1 orang mempunyai kemauan yang rendah. Dari hasil tersebut dapat disimpulkan bahwa masyarakat mempunyai kemauan yang tinggi terhadap minat bersepeda pada masa pandemi covid 19 .

4. Indikator Lingkungan

Dalam indikator lingkungan terdapat lima belas item pernyataan. Pernyataan yang telah dijawab oleh responden memperoleh skor rata-rata 57 dengan persentase $76 \%$ masuk kedalam kategori tinggi. Untuk mengetahui hasil persentase dapat dilihat pada tabel sebagai berikut:

Tabel 5. Distribusi Minat Masyarakat Indikator Lingkungan

\begin{tabular}{cccc}
\hline No & Persentase & Kriteria & Frekuensi \\
\hline $\mathbf{1}$ & $81 \%-100 \%$ & Sangat Tinggi & 30 \\
\hline
\end{tabular}


Survey minat masyarakat untuk olahraga rekreasi Bersepeda pada masa pandemi covid 19 di demak

\begin{tabular}{cccc}
\hline $\mathbf{2}$ & $61 \%-80 \%$ & Tinggi & 67 \\
\hline $\mathbf{3}$ & $41 \%-60 \%$ & Cukup & 3 \\
\hline $\mathbf{4}$ & $21 \%-40 \%$ & Rendah & 0 \\
\hline $\mathbf{5}$ & $0 \%-20 \%$ & Sangat Rendah & 0 \\
\hline \multicolumn{3}{c}{ Jumlah } & 100 \\
\hline
\end{tabular}

Berdasarkan dari gambar diatas dapat diketahui bahwa terdapat 30 orang masuk dalam kategori sangat tinggi, 67 orang dalam kategori tinggi, dan 3 orang dalam kategori cukup. Dari hasil tersebut dapat disimpulkan bahwa lingkungan mempunyai peranan yang penting terhadap minat masyarakat untuk olahraga rekreasi bersepeda pada masa pandemi covid 19.

5. Indikator Sarana dan Prasarana

Dalam indikator sarana dan prasarana terdapat lima belas item pernyataan. Pernyataan yang telah dijawab oleh responden memperoleh skor rata-rata 57 dengan persentase $76 \%$ masuk kedalam kategori tinggi. Untuk mengetahui hasil persentase dapat dilihat pada tabel sebagai berikut:

Tabel 6. Distribusi Minat Masyarakat Indikator Sarana dan Prasarana

\begin{tabular}{cccc}
\hline No & Persentase & Kriteria & Frekuensi \\
\hline $\mathbf{1}$ & $81 \%-100 \%$ & Sangat Tinggi & 13 \\
\hline $\mathbf{2}$ & $61 \%-80 \%$ & Tinggi & 78 \\
\hline $\mathbf{3}$ & $41 \%-60 \%$ & Cukup & 9 \\
\hline $\mathbf{4}$ & $21 \%-40 \%$ & Rendah & 0 \\
\hline $\mathbf{5}$ & $0 \%-20 \%$ & Sangat Rendah & 0 \\
\hline \multicolumn{3}{c}{ Jumlah } & 100 \\
\hline
\end{tabular}

Berdasarkan dari gambar diatas dapat diketahui bahwa terdapat 13 orang masuk dalam kategori sangat tinggi, 78 orang dalam kategori tinggi, dan 9 orang dalam kategori cukup. Dari hasil tersebut dapat disimpulkan bahwa sarana dan prasarana mempunyai peranan yang penting terhadap minat masyarakat untuk olahraga rekreasi bersepeda pada masa pandemi covid 19.

\section{KESIMPULAN}

Berdasarkan penelitian dapat disimpulkan bahwa minat masyarakat untuk olahraga rekreasi bersepeda pada masa pandemi covid 19 masuk dalam kategori tinggi dengan persentase $75 \%$ dengan perolehan skor rata-rata 282. Masyarakat dengan kriteria sangat tinggi sebanyak 24 orang, kriteria tinggi sebanyak 73 orang, dan kriteria cukup sebanyak 3 orang. Jika ditinjau dari indikator minat masyarakat maka indikator perhatian yang paling dominan dengan perolehan persentase sebesar $78 \%$ dengan kategori tinggi. Masyarakat berpendapat bahwa bersepeda merupakan olahraga yang cocok yang dilakukan pada masa pandemi, pada masa pandemi kesehatan merupakan hal yang harus paling kita jaga karena tubuh rentan terkena virus. Dengan bersepeda kita masih bisa menjaga protokol kesehatan yang telah diterapkan dimasa pandemi ini. 


\section{DAFTAR PUSTAKA}

Alfurqon, F. A. 2017. Efektivitas Pembelajaran Berbantuan Video Game Visual Novel Untuk

Meningkatkan Minat Belajar Matematika Peserta Didik. Semarang: Universitas Negeri Semarang

Arifin, V. S. M. 2015. Survei Minat Masyarakat Untuk Melakukan Aktivitas Olahraga Di Gor Tri Lomba Juang Semarang Tahun 2015. Semarang: Universitas Negeri Semarang

Ariyanto, S. 2016. Motivasi Olahraga Rekreasi Pada Pengunjung Desa Wisata Kampoeng Djowo Sekatul Kecamatan Limbangan Kabupaten Kendal Tahun 2016. Semarang: Universitas Negeri Semarang

Aturrohmi, I. 2017. Pengaruh Lingkungan Pendidikan Terhadap Minat Belajar IPS Siswa Kelas X MA Al Maarif Singosari Malang. Malang: Universitas Islam Negeri Maulana Malik Ibrahim

Chris Carmichael.2003.Bugar dengan Bersepeda.Jakarta:PT Raja Grafindo Persada.

Hidayat, A. 2015. Survei Perkembangan Olahraga Rekreasi Gateball Di Kabupaten Semarang. Semarang: Universitas Negeri Semarang

Kusuma, B. A. \& Setyawati, H. 2016. Survei Faktor-Faktor yang Mempengaruhi Minat Olahraga Rekreasi Akhir Pekan di Alun-Alun Wonosobo. Jurnal Active. 5 (2) 67-73.

Munasifah. 2019. Mengenal Olahraga Balap Sepeda. Tangerang: Loka Aksara

Mustofa, M. 2018. Minat Siswa dalam Ekstrakulikuler Olahraga Futsal di SMA N 1 Pamotan Kabupaten Rembang. Semarang: Universitas PGRI Semarang

Pranata, A. Y. 2016. Survei Minat Dan Motivasi Masyarakat Untuk Bersepeda Pada Pelaksanaan “Jogja Last Friday Ride” Di Kota Yogyakarta. Semarang: Universitas Negeri Semarang

Rosalia, H. 2019. Faktor-Faktor Yang Mempengaruhi Minat Olahraga Rekreasi Akhir Pekan Di AlunAlun Kabupaten Tegal Tahun 2019. Semarang: Universitas Negeri Semarang

Rosdiani, D. 2013. Dinamika Olahraga dan Pengembangan Nilai. Bandung: ALFABETA.

Satriawan, D. 2015. Survei Minat Masyarakat Terhadap Pemanfaatan Ruang Terbuka Publik Sebagai Tempat Berolahraga Di Kota Salatiga Tahun 2013. Jurnal Active. 4 (3) 1666-1672.

Septiarso, J. F. 2015. Survei Manajemen Wahana Olahraga Rekreasi Widuri Water Park Kabupaten 
Survey minat masyarakat untuk olahraga rekreasi Bersepeda pada masa pandemi covid 19 di demak

Taufik hidayat, maftukin hudah, utvi hinda zhannisa,

Pemalang Tahun 2014. Semarang: Universitas Negeri Semarang

Sugiyono. 2016. Metode Penelitian Kuantitatif, Kualitatif, dan R\&D. Bandung: Alfabeta.

Suratmin. 2018. Pengantar Olahraga Rekreasi dan Olahraga Pariwisata. Depok: Rajawali Pers.

Tejokusumo, B. 2014. Dinamika Masyarakat Sebagai Sumber Belajar Ilmu Pengetahuan Sosial. Jurnal Geoedukasi Volume III Nomor 1 halaman 38-43.

Trinovrianti. 2012. Gambaran Zona Latihan Saat Bersepeda Pada Anggota Fixie Bike Makassar Tahun 2012. Makassar: Universitas Hasanuddin Makassar

Undang-undang Republik Indonesia Nomor 3 Tahun 2005. Diambil dari: www.dpr.go.id/dokjdih/uu. (27 Juli 2020).

Utomo, U. 2015. Survei Minat Terhadap Olahraga Rekreasi Melalui Car Free Day Sebagai Aktivitas Peningkatan Kebugaran Jasmani Di Alun Alun Jepara Tahun 2015. Semarang: Universitas Negeri Semarang 